InOedia $\quad \begin{aligned} & \text { InMedia } \\ & \text { The French Journal of Media Studies }\end{aligned}$

8.1. $\mid 2020$

Ubiquitous Visuality

\title{
Man Ray and Fashion / Man Ray et la mode - Musée du Luxembourg, Paris
}

Man Ray et la mode, Musée du Luxembourg, Paris, curators: Xavier Rey, Alain Sayag, Catherine Örmen

\section{Clémentine Tholas}

\section{(2) OpenEdition}

\section{Journals}

Electronic version

URL: http://journals.openedition.org/inmedia/2221

DOI: 10.4000/inmedia.2221

ISSN: 2259-4728

Publisher

Center for Research on the English-Speaking World (CREW)

\section{Electronic reference}

Clémentine Tholas, "Man Ray and Fashion / Man Ray et la mode - Musée du Luxembourg, Paris", InMedia [Online], 8.1. | 2020, Online since 15 July 2020, connection on 28 January 2021. URL: http:// journals.openedition.org/inmedia/2221 ; DOl: https://doi.org/10.4000/inmedia.2221

This text was automatically generated on 28 January 2021.

(C) InMedia 


\section{Man Ray and Fashion / Man Ray et la mode - Musée du Luxembourg, Paris}

Man Ray et la mode, Musée du Luxembourg, Paris, curators: Xavier Rey, Alain Sayag, Catherine Örmen

\section{Clémentine Tholas}

1 As the museumgoer enters the first room of the exhibition "Man Ray and Fashion", he/ she is plunged into a Dadaist ${ }^{1}$ interpretation of what fashion can mean thanks to a picture of a flat iron adorned with brass tacks entitled The Gift/ Cadeau (1921) and a massive installation made of sixty-three wooden coat hangers, Obstruction (1920). The surrealist dimension of Man Ray's work is apparent through these two art pieces conveying an image of the world of fashion as unfrivolous or unglamorous but as industrious and industrial in the context of an emerging consumer society. Like many surrealist productions diverting objects from their original purpose and using fantasy and humor to question the non-sensical aspects of everyday life, The Gift and Obstruction seem to be used to set the tone; they encourage the viewers to interrogate what they may discover in this exhibition staging commissioned pictures taken by the American photographer in the 1920s and 1930s for famous fashion magazines like Harper's Bazar or Vogue. After following Marcel Duchamp's advice and crossing the Pond to come to Paris in 1921, Man Ray started working in the fashion circle transforming fashion photography. Without totally differing from the signature of his most famous works of art, Ingres's Violin / Le Violon d'Ingres (1924) or Black and White / Noir et Blanc (1926), these fashion photographs appear as a gateway to deconstruct and reconstruct fashion, allure, beauty.

2 The second room shows various portraits of 1920s models wearing stylish outfits created by French designers like Coco Chanel, Elsa Schiaparelli or Paul Poiret and also displays the original dresses worn in the pictures. The spectator can see an intriguing series of black and white photographs revealing elegant women with saddened looks and dark rings under their eyes, reminiscent of the frightening and gloomy aesthetic of 
German impressionist cinema ${ }^{2}$ popularized during the same decade. Despite his American origins, Man Ray's perception of femininity seems inspired by European ideals created in a post-World War One society instead of looking up to the American vision of seductive female splendor conveyed by Hollywood which had already become a dominant cultural media at that time. The women in the pictures appear to be motionless, aloof beauties adopting a stern attitude. The indifferent magnetism of the models is captured and their behavior gives new perspectives on conventional definitions of attraction and style. In Man Ray's vision, women are adorned with glittering embroidered evening dresses but they remain detached and dejected, their doleful eyes contrasting with their sophisticated hairstyle and clothing, as if they were vaguely aware of the hollow masquerade produced by fashion. Joan Riviere's theory on women willingly wearing a mask in order to hide their true feelings and aspirations and conform to social norms ${ }^{3}$ easily comes to mind; these outlandish pictures seem to a certain extent to expose the shallow subterfuge of fashion as a rather futile embellishment unable to fully cover the general melancholy of the time.

3 Then follows an excerpt from The Mysteries of the Chateau of Dice/ Le Mystère du chateau du Dé (1929), Man Ray's last attempt at filmmaking. The clip stages faceless swimmers in the pool of the Villa de Noailles and offers a performance centered on the body. After focusing on the facial expressions of reserved women, Man Ray plays with physical movement in the water and compares the group to circus jugglers, trapeze artists, before associating some swimmers with deities. He also edits backwards some dives and provides sideways shots of shadows over the water. This visual experimentation makes the spectator reflect upon the freedom and recreation of the body, diverging from the rigid codes imposed by social events. The film is also pitted against a series of party pictures; indeed, Man Ray portrayed his well-off entourage during sophisticated festivities and bacchanalias in fancy-dresses which contrast with the simplicity of the swimming bodies and the spontaneous childlike attitude of the bathers. This part of the exhibition seems to examine the activities of social circles, the new craze for sport and the fascination with healthy bodies after years of psychological and physical deprivation. He captures the frenzy of a world reborn full of life and eccentricities.

4 After grasping Man Ray's sensibility and perception of society, the second part of the exhibition is devoted to the fashion pictures per se. More conventional full size photographs and experimental compositions are presented to the viewer. In the magazine-commissioned pictures, Ray inventively introduces an artistic touch which magnifies the models and their grandiose outfits with light effects, superimpositions, colorizations or other technical experiments. One of the models, Lee Miller, his muse and lover, was herself a photographer who learned her trade from the intellectual exchanges with her mentor. In front of his camera, she becomes the woman of a thousand faces, the embodiment of a polymorphous femininity. Man Ray's fashion pictures convey an atmosphere of unreal serenity and completeness, a dream-like perception of graceful women clad in sumptuous apparels making them look like modern-time goddesses. This deification of female beauty is reminiscent of the new cult devoted to cinema stars since the rise of the American film industry in the 1920 s which turns performers into new objects of quasi-religious worship. However, the photographer seizes the evolution from the creative agitation of the Roaring Twenties with shorter eccentric dresses revealing the anatomy to the reclaimed conformism of the 1930s when garments were a tad longer and stricter; he is an observer of social 
transformations and his pictures bear witness to the improvements and regressions women were faced with during the interwar period.

The exhibition also displays Man Ray's interest for fashionable details and accessories such as hairdos with a case showing a collection of wigs, nail art and make-up. One of his masterpieces, Les Larmes / Glass Tears (1932), created for a water-proof mascara brand, appears as a study of the mise-en-scène of women's eyes with the use of maquillage and artefacts. Inspired by his stormy relationship with Lee Miller, Glass Tears offers a close-shot on the mascara-coated lashes of a model whose distress is emphasized by glistening tear drops (made of glass beads) under her eyes. This iconic creation underlines artificiality of the model's sorrow but also the phoniness of a beauty based on the intense use of cosmetics. Man Ray seems to mock the synthetic world which however provides him with work and money. Through a series of proofs, we discover the experimental process used to produce this well-known image and measure the major contributions of Man Ray to developing a more aesthetic and innovative approach to publicity. The exhibition enhances the encounter, the collision between art and early consumer culture.

\section{NOTES}

1. Dadaism is an early $20^{\text {th }}$ century movement based on an anti-aesthetic approach in order to express the non-sense of post-WWI society. The movement favored collaborations in collage, photomontage, object-construction in order to mock the art establishment and bourgeois values. 2. At its height in the 1920s, German expressionism is associated with intense contrasts of dark and light, distorted images in order to create a nightmarish atmosphere and it is based on a depiction of reality altered by emotional distress. Connected with architecture and painting, the genre became mainly popular thanks to cinema and its visual experimentation to render inner subjective experiences and signify the absurdity of a society broken by the Great War.

3. Joan Rivière, "Womanliness as a masquerade ", International Journal of Psycho-Analysis, Vol 9 (1929), 303-313.

\section{AUTHOR}

\section{CLÉMENTINE THOLAS}

Clémentine Tholas is associate professor of American Studies at Sorbonne Nouvelle University. She is a silent film scholar and a specialist of war cinema. 